\title{
Factors Controlling the Spatial Distribution and Temporal Trend of Nationwide Groundwater Quality in Korea
}

\author{
Chang-Seong Kim ${ }^{1} \oplus$, Maimoona Raza ${ }^{1}$, Jin-Yong Lee ${ }^{1, *}{ }^{\oplus}$, Heejung Kim ${ }^{1} \oplus$, \\ Chanhyeok Jeon ${ }^{1}$ D, Bora Kim ${ }^{2}$, Jeong-Woo Kim ${ }^{2}$ and Rak-Hyeon Kim ${ }^{3}$ \\ 1 Department of Geology, Kangwon National University, Chuncheon 24341, Korea; \\ kcs@kangwon.ac.kr (C.-S.K.); maimoonaraza14@gmail.com (M.R.); hydroqueen@kangwon.ac.kr (H.K.); \\ jeonchan0424@kangwon.ac.kr (C.J.) \\ 2 GeoGreen21 Co., Ltd., Seoul 08376, Korea; hathor8417@geogreen21.com (B.K.); \\ wjddnkim@geogreen21.com (J.-W.K.) \\ 3 Korea Environment Corporation, Incheon 22689, Korea; acezeta@keco.or.kr \\ * Correspondence: hydrolee@kangwon.ac.kr
}

Received: 23 September 2020; Accepted: 27 November 2020; Published: 28 November 2020

\begin{abstract}
Factors controlling the spatial distribution and temporal trend of groundwater quality at a national scale are important to investigate for sustaining livelihood and ecological balance. This study evaluated groundwater quality data for 12 parameters ( $\mathrm{n}=6405$ for each parameter), collected from 97 groundwater monitoring stations (=289 monitoring wells) for ten years. Spatial distribution of groundwater quality parameters varied through the regional scale. Six parameters: T, EC, $\mathrm{Ca}^{2+}$, $\mathrm{Mg}^{2+}, \mathrm{HCO}_{3}{ }^{-}$, and $\mathrm{Cl}^{-}$were having dominant increasing trend, remaining $\mathrm{pH}, \mathrm{Eh}, \mathrm{Na}^{+}, \mathrm{K}^{+}, \mathrm{SO}_{4}{ }^{2-}$, and $\mathrm{NO}_{3}{ }^{-}$showed a dominant decreasing trend over time. Among land use types, the upland fields had the highest mean of groundwater $\mathrm{NO}_{3}{ }^{-}(22.2 \mathrm{mg} / \mathrm{L})$, confirming plenty of application of fertilizers (5-10 kg/a more than standard) to upland fields. Means of groundwater $\mathrm{Cl}^{-}$and $\mathrm{Na}^{+}$ (705.3 and $298.4 \mathrm{mg} / \mathrm{L}$, respectively) in the residential areas are greater than those in other land use types by 408-685.9, 154.3-274.2 mg/L, respectively. Agricultural activities were the main controlling factor of groundwater $\mathrm{NO}_{3}{ }^{-}$contamination in rural areas, domestic activities were responsible for groundwater $\mathrm{Cl}^{-}$and $\mathrm{Na}^{+}$in urban areas, and seawater intrusion was controlling groundwater $\mathrm{Cl}^{-}$in coastal areas (within $10 \mathrm{~km}$ from sea). Groundwater hydrochemistry was controlled by the mechanism of geogenic rock and evaporation dominance. The rock dominance mechanism indicated that groundwater was interacting with rocks and resulted in groundwater chemistry. The findings of this study showed that groundwater was mainly contaminated by anthropogenic factors in some rural and residential areas. Effective measures by government authorities are needed to improve the groundwater quality.
\end{abstract}

Keywords: groundwater quality; spatial distribution; temporal trend; agricultural activities; domestic sewage; seawater intrusion; hydrochemical mechanism

\section{Introduction}

The quality of groundwater, influenced by several anthropogenic and natural factors, is one of the most profound issues worldwide [1]. The groundwater chemistry is controlled mostly by chemical weathering, evapotranspiration, anthropogenic interferences, and precipitation [2]. The study on chemical characteristics of groundwater has wide implications for managing water quality, as it enables understanding the chemical composition of groundwater and suggest appropriate management plans $[3,4]$. The groundwater quality is affected particularly by agricultural activities, industrial and 
domestic sewage, and seawater intrusion in coastal areas [5-7]. Anthropogenic factors are the most common cause of groundwater quality deterioration among natural and anthropogenic factors [8].

To manage and preserve groundwater, it is necessary to evaluate the status and variability of groundwater quality. In this regard, the Korean government regularly monitors groundwater quality to develop basic guidelines for groundwater policy [9]. Therefore, the government operates several monitoring networks, including the Groundwater Quality Monitoring Network (GQMN) operated by Korea Environment Corporation (KECO), which is affiliated with the Ministry of Environment (ME), and the National Groundwater Monitoring Network (NGMN) operated by K-water, which is also affiliated with the ME [9]. The GQMN monitors groundwater quality on a national scale every quarter with several parameters, including field measured parameters and major ions. Each monitoring station of GQMN comprises one to three wells with different depths (5.5-79 m). The regions under GQMN are divided into uncontaminated (background) regions and already contaminated (or suspected contamination) regions [10].

The spatiotemporal variations of groundwater quality can also be understood according to the different statistical analysis [11]. Alongside, the chemical characteristics of groundwater can be identified by multivariate statistical analysis and ionic relationships [12]. The broad use of multiple methods is useful to confirm the characteristics and factors controlling groundwater quality [11,12]. In Algeria, groundwater chemistry was investigated using multivariate statistical analysis and geochemical modeling techniques [13]. Major factors controlling groundwater chemistry were found to be geological, due to the presence or dissolution of silicate, carbonate, and evaporite minerals. There were 18 groundwater wells in their study area, making it difficult to represent the groundwater quality of the entire region. In the United Kingdom, groundwater nitrate was assessed using various methodologies, such as ordinary least squares linear regression, robust linear regression, and Sen's slope test [14]. They reported that groundwater quality and aquifer properties varied on daily, seasonal, and annual time scales. The underlying cause of quality variations was concluded to be changes in fertilizer application, land use, and climate.

In Korea, groundwater quality was examined in 2014 for 374 monitoring wells of NGMN, and concentrations of some ions (calcium, magnesium, sodium, potassium, and silicon) were estimated and mapped using the kriging method [15]. In another study, distribution of groundwater quality was investigated for 320 groundwater wells, installed to produce commercial drinking water, and the groundwater qualities in different regions were compared [16]. The mean values of 8 parameters (calcium, magnesium, sodium, potassium, chloride, nitrate, sulfate, and fluoride) were 21, 3.4, 9.6, 1, 8, $6.6,12$, and $0.5 \mathrm{mg} / \mathrm{L}$, respectively, in 2015 of the inland areas. These two investigations were studied for only one year and did not analyze the temporal changes in groundwater chemistry.

It is complex to evaluate relationship of diverse sources and processes with different parameters [7]. Nevertheless, it is necessary to evaluate status and changes of groundwater quality parameters. The study can improve water resource policies related to groundwater contamination and protect human health by increasing public awareness [10]. Furthermore, this is topic for ensuring quantity of available water resources in response to the changing climate [14]. In this regard, some studies have assessed distribution or trend of groundwater quality at local level $[7,11,13]$, but there is a need for complete understanding of factors that are controlling spatiotemporal variations in groundwater quality at national level. In order to generate appropriate treatment plan for the groundwater quality, the investigation of main factors that are controlling the groundwater quality, based on a long-term temporal and countrywide spatial study is required. The objectives of this study are to evaluate the spatial distribution and temporal trend of groundwater quality on a national scale and elaborate on the factors that are controlling the distribution of groundwater quality. The findings of this study will be useful to understand the reasons behind deteriorated or good groundwater quality in regions, having similar settings (geological and climatic) and surroundings (nearby land use type: agricultural, residential, industrial, or coastal). 


\section{Methods and Materials}

\subsection{Study Area, Hydrometeorology, and Land Use}

The study area is located in East Asia, in the southern half of Korean peninsula, between $34-38^{\circ} \mathrm{N}$ and $124-130^{\circ} \mathrm{E}$. The total area of the country is approximately $100,000 \mathrm{~km}^{2}$, and forests comprise $70 \%$ out of the total area. Also, the far eastern, western, and southern parts of the country are surrounded by seas (East Sea, West Sea, and South Sea). The climate is hot and humid in summer and cold and dry in winter. Average annual precipitation is $1200-1400 \mathrm{~mm}, 50-60 \%$ of which occurs in summer, and average annual air temperature is $10-16{ }^{\circ} \mathrm{C}$ [17]. The East Asian monsoon mainly affects the climate of the study area.

The land surface exhibits various types of land use, with dominant land uses of the monitoring stations being forests (35\% (34 out of 97)), upland fields ( $26 \%$ ), rice paddies (24\%), and residential areas (15\%; Figure 1). Large forests and croplands (upland fields and rice paddies) are distributed throughout the country. Subsurface geology of monitoring wells (where the monitoring wells are tapped) is granite $(25 \%$ (73 out of 289$)$ ), alluvium $(17 \%)$, gneiss $(16 \%)$, sandstone $(12 \%)$, limestone $(5 \%)$, shale $(4 \%)$, schist $(4 \%)$, andesite $(4 \%)$, tuff $(4 \%)$, and other $(9 \%)$. Approximately $75 \%$ of igneous rocks are granite, $46 \%$ and $18 \%$ of sedimentary rocks are sandstone and limestone, respectively, and $71 \%$ of metamorphic rocks are gneiss. Groundwater chemistry is basically affected by the minerals constituting the rocks of the aquifer. In particular, major cations (calcium, magnesium, sodium, and potassium), that are present in large amounts in groundwater, are usually derived from the geological settings [18]. Groundwater quality may vary spatially because of differences in land use and geology $[4,13,19]$. Therefore, the information (land uses and subsurface geologies) as well as groundwater quality data were obtained from KECO for this study. The land use and geology at the time of the installation of the GQMN monitoring well were used in this study.
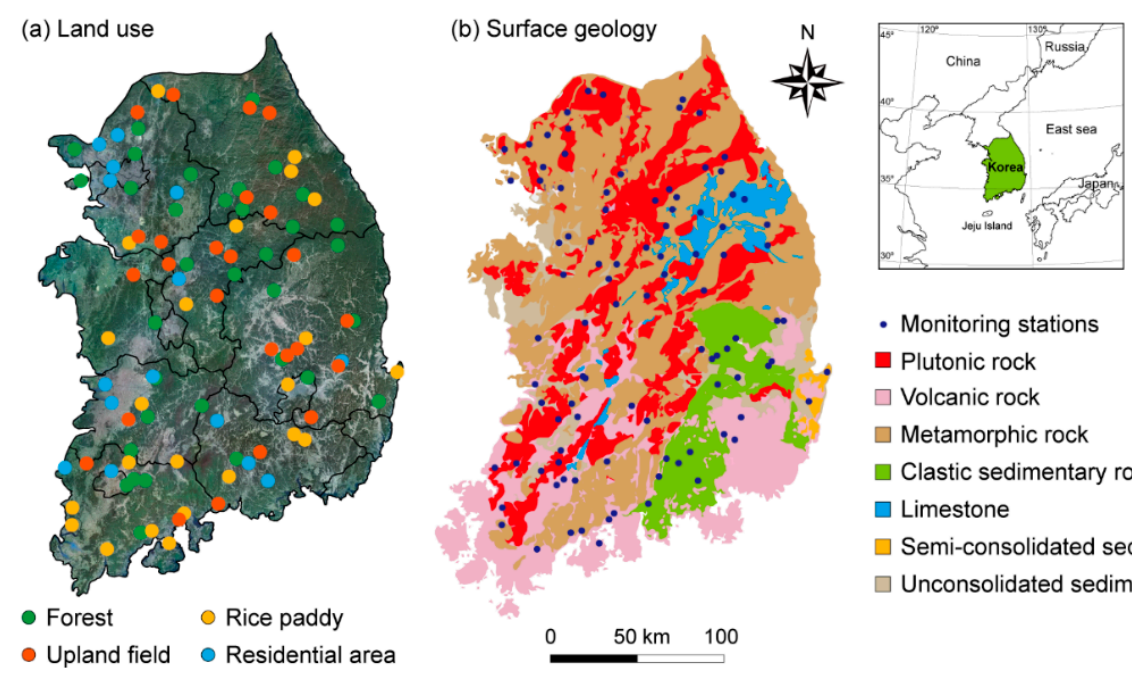

- Monitoring stations

- Plutonic rock

$\square$ Volcanic rock

Metamorphic rock

Clastic sedimentary rock

$\square$ Limestone

$\square$ Semi-consolidated sedimentary rock

$\square$ Unconsolidated sediment

Figure 1. (a) Map showing land use (solid circles) for each monitoring station of GQMN ( $n=97)$. Land use types were investigated at the time when monitoring stations were installed. The background is a satellite image of Korea. (b) Surface geology of the country (modified from Bacal et al. [20]). Solid circles indicate each monitoring station.

\subsection{Collection of Groundwater Quality Data}

We collected groundwater quality data from 289 monitoring wells at 97 monitoring stations for the duration 2008-2017 (number of data (n) = 6405 for each parameter). The data used in this study were from monitoring stations of GQMN installed in background regions. Groundwater quality depends on the location of monitoring stations $[14,17]$. Thus, we examined their locations with the different installation dates. The number of monitoring stations increased steadily each year after 
installation of the wells, from only three monitoring stations in 2007 to 97 stations in 2016, covering all administrative districts of the country since 2017 (Figure 2). Twelve groundwater quality parameters were selected to study the hydrochemistry including: temperature $(\mathrm{T}), \mathrm{pH}$, electrical conductivity $(\mathrm{EC})$, oxidation reduction potential (Eh), calcium $\left(\mathrm{Ca}^{2+}\right)$, magnesium $\left(\mathrm{Mg}^{2+}\right)$, sodium $\left(\mathrm{Na}^{+}\right)$, potassium $\left(\mathrm{K}^{+}\right)$, bicarbonate $\left(\mathrm{HCO}_{3}{ }^{-}\right)$, chloride $\left(\mathrm{Cl}^{-}\right)$, sulfate $\left(\mathrm{SO}_{4}{ }^{2-}\right)$, and nitrate $\left(\mathrm{NO}_{3}{ }^{-}\right)$. The eight parameters $\left(\mathrm{Ca}^{2+}\right.$, $\mathrm{Mg}^{2+}, \mathrm{Na}^{+}, \mathrm{K}^{+}, \mathrm{HCO}_{3}{ }^{-}, \mathrm{Cl}^{-}, \mathrm{SO}_{4}{ }^{2-}$, and $\left.\mathrm{NO}_{3}{ }^{-}\right)$are indicative of geochemical evolutions including water-rock interaction, ion exchange, etc. In the meanwhile, the distribution and trend of $\mathrm{Na}^{+}, \mathrm{Cl}^{-}$, $\mathrm{SO}_{4}{ }^{2-}$, and $\mathrm{NO}_{3}{ }^{-}$can be analyzed to determine whether groundwater is contaminated by natural or anthropogenic factors. The four parameters ( $\mathrm{T}, \mathrm{pH}, \mathrm{EC}$, and $\mathrm{Eh}$ ) are measured in the field site as they are sensitive to redox conditions.

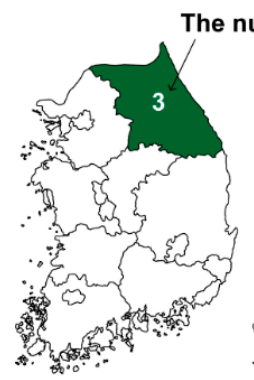

2008

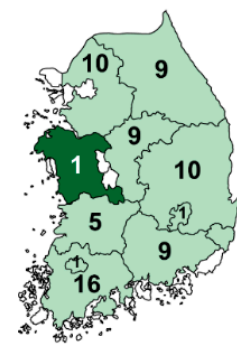

2013

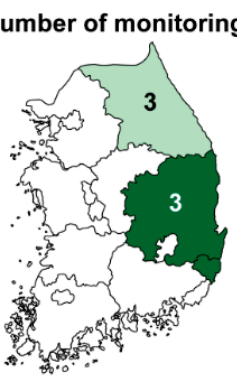

2009

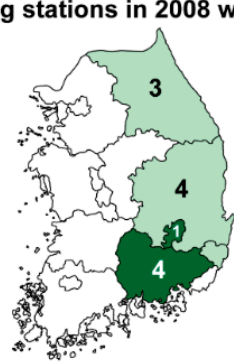

2010

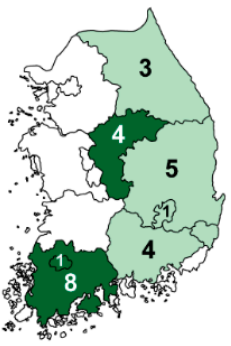

2011

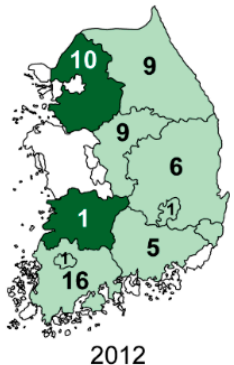

2012

The number of monitoring stations in 2014 was 97.

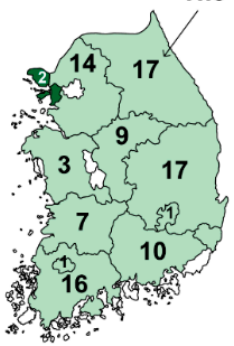

2014

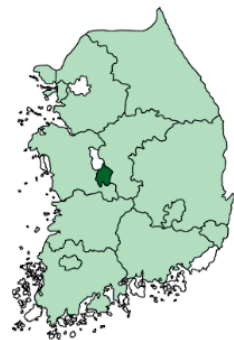

2015

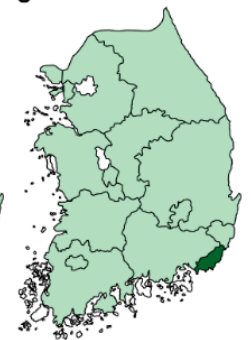

2016

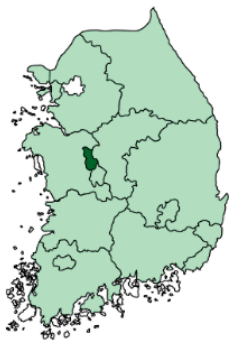

2017 N

New monitoring region

Previous monitoring region

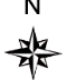

Figure 2. Expansion of groundwater quality monitoring stations from 2008 to 2017.

All methods used to obtain groundwater samples, conduct preprocessing, and perform water quality analysis were complied with the ME regulations [21]. All groundwater samples were obtained using a peristaltic pump or disposable bailer. Four parameters ( $\mathrm{T}, \mathrm{pH}, \mathrm{EC}$, and Eh) were measured in the field using portable meters. Groundwater samples were collected to analyze for major cations and anions $\left(\mathrm{Ca}^{2+}, \mathrm{Mg}^{2+}, \mathrm{Na}^{+}, \mathrm{K}^{+}, \mathrm{HCO}_{3}{ }^{-}, \mathrm{Cl}^{-}, \mathrm{SO}_{4}{ }^{2-}\right.$, and $\left.\mathrm{NO}_{3}{ }^{-}\right)$in water and were preserved in 30-125 mL polyethylene or glass bottles after filtering with $0.45 \mu \mathrm{m}$ cellulose membrane filters. For cation analysis, nitric acid was added to a polyethylene bottle after filtering to maintain $\mathrm{pH}<2$. The water samples were stored at $4{ }^{\circ} \mathrm{C}$ until laboratory analysis. The hydrochemical data are reliable, with an ionic charge balance error for each sample of less than $10 \%$ [21].

\subsection{Statistical Data Analysis}

This study evaluated nationwide groundwater quality from 2008 to 2017 using quarterly data from GQMN. Some data were excluded if the monitoring period was less than four years or the number of measurements was less than 15, which may lead to statistical errors [14]. Descriptive statistics were performed to interpret the spatial and temporal variations in the dataset. For evaluation of the spatial distribution, we calculated as median of groundwater quality of the two or three well depths (shallow, intermediate, and deep). Using these data, we assessed the impact of land use on groundwater quality as well as the spatial distribution of groundwater hydrochemistry. For trend analysis, groundwater 
quality at each monitoring well was analyzed using a linear regression, which is a type of parametric analysis $[14,17]$. According to Central Limit Theorem, the sample number was reasonably large $(n>30)$, and applicable for parametric test on the data [22,23]. Linear regression analysis is used to determine monotonic increasing or decreasing trend, and the least squares method is applied to calculate the linear regression. However, in linear regression analysis, the slope may vary depending on outliers [14]. A box-whisker diagram was used to visualize the approximate distribution of data and comparisons of the dataset under different parameters from 2008 to 2017. Gibbs diagrams were plotted to determine main processes controlling the groundwater chemistry in the study area. Total dissolved solids (TDS) values used in Gibbs plots were the sum of ionic values for $\mathrm{Ca}^{2+}, \mathrm{Mg}^{2+}, \mathrm{Na}^{+}, \mathrm{K}^{+}, \mathrm{HCO}_{3}{ }^{-}, \mathrm{Cl}^{-}, \mathrm{SO}_{4}{ }^{2-}$, and $\mathrm{NO}_{3}{ }^{-}$analyzed in groundwater samples. Pearson correlation analysis was used to determine the relationship between the considered parameters. Multivariate statistical analysis was used for understanding and classification of large environmental datasets. Principal component analysis (PCA) was applied to the dataset to reduce the analytical data collected from different monitoring stations and to analyze the percent of variance explained by different parameters of groundwater quality [12].

\section{Results and Discussion}

\subsection{General Chemistry of Groundwater}

The statistical summary of groundwater chemistry of 6405 water samples, obtained from 97 monitoring stations of GQMN in Korea, is given in Table 1. Median values are more appropriate to find the dominant pattern of ions in water when the parameters data is large or is showing not normal distribution [14]. For the large dataset used in this study, median values are considered because of high variability in different groundwater parameters. The groundwater temperature ranged from 4.4 to $27.8^{\circ} \mathrm{C}$ with a median of $15.8^{\circ} \mathrm{C}$. Generally, groundwater temperature is affected by soil and air temperature. The groundwater $\mathrm{pH}$ ranged from 4.3 to 10.4 with a median of 6.9 , which showed that water varied from acidic to alkaline in nature. Remediation methods on contaminated groundwater vary depending on whether the $\mathrm{pH}$ is acidic or alkaline, because the solubility of dissolved contaminants varies with varying $\mathrm{pH}$ value [24]. The value of groundwater EC showed great variations from 46 to $48,100 \mu \mathrm{S} / \mathrm{cm}$, with the median of $317 \mu \mathrm{S} / \mathrm{cm}$. In the total duration of study (2008-2017), 74 out of 6405 groundwater samples showed EC $>9000 \mu \mathrm{S} / \mathrm{cm}$, which is characteristic of seawater. This indicated the influence of seawater intrusion to groundwater in the coastal areas [25].

Table 1. Descriptive statistics of groundwater quality parameters for 2008-2017 ( $n=6405$ for each parameter).

\begin{tabular}{cccccccc}
\hline Parameters & Maximum & Minimum & Mean & Median & SD $^{\mathbf{1}}$ & $\mathbf{C V}^{\mathbf{2}}$ & ND $^{\mathbf{3}}(\%)$ \\
\hline $\mathrm{T}\left({ }^{\circ} \mathrm{C}\right)$ & 27.8 & 4.4 & 15.9 & 15.8 & 2.3 & 0.15 & 0 \\
$\mathrm{pH}$ & 10.4 & 4.3 & 7.0 & 6.9 & 0.8 & 0.11 & 0 \\
$\mathrm{EC}(\mu \mathrm{S} / \mathrm{cm})$ & 48,100 & 46 & 769 & 317 & 3586 & 4.66 & 0 \\
$\mathrm{Eh}(\mathrm{mV})$ & 892 & -159 & 288 & 302 & 123 & 0.43 & 0 \\
$\mathrm{Ca}^{2+}(\mathrm{mg} / \mathrm{L})$ & 4000 & $<0.05$ & 57.1 & 26.5 & 232 & 4.06 & 0.2 \\
$\mathrm{Mg}^{2+}(\mathrm{mg} / \mathrm{L})$ & 2357 & 0.03 & 20.8 & 6.8 & 113 & 5.43 & 0.2 \\
$\mathrm{Na}^{+}(\mathrm{mg} / \mathrm{L})$ & 8640 & $<0.05$ & 99.8 & 17.8 & 601 & 6.02 & 0.02 \\
$\mathrm{~K}^{+}(\mathrm{mg} / \mathrm{L})$ & 3200 & $<0.05$ & 5.0 & 2.4 & 41.3 & 8.26 & 0.02 \\
$\mathrm{HCO}_{3}{ }^{-}(\mathrm{mg} / \mathrm{L})$ & 1198 & 1.0 & 127 & 102 & 95.1 & 0.75 & 0 \\
$\mathrm{Cl}^{-}(\mathrm{mg} / \mathrm{L})$ & 30,479 & $<0.05$ & 201 & 13.3 & 1550 & 7.71 & 0.02 \\
$\mathrm{SO}_{4}{ }^{2-}(\mathrm{mg} / \mathrm{L})$ & 1983 & $<0.05$ & 46.6 & 14.5 & 162 & 3.48 & 2.6 \\
$\mathrm{NO}_{3}{ }^{-}(\mathrm{mg} / \mathrm{L})$ & 368 & $<0.05$ & 16.8 & 6.9 & 30.4 & 1.81 & 13.1 \\
\hline
\end{tabular}

The values of groundwater Eh were mostly positive, ranged from -159 to $892 \mathrm{mV}$ with median of $302 \mathrm{mV}$. The high and positive Eh values recommend that hydrogeological reactions are more likely to occur naturally without some external energy. The median values for groundwater major 
cations: $\mathrm{Ca}^{2+}, \mathrm{Mg}^{2+}, \mathrm{Na}^{+}$, and $\mathrm{K}^{+}$were $26.5,6.8,17.8$, and $2.4 \mathrm{mg} / \mathrm{L}$, respectively. Based on the median $(\mathrm{mg} / \mathrm{L})$, the pattern of cationic dominance was followed by $\mathrm{Ca}^{2+}>\mathrm{Na}^{+}>\mathrm{Mg}^{2+}>\mathrm{K}^{+}$in groundwater. The median of groundwater major anions: $\mathrm{HCO}_{3}{ }^{-}, \mathrm{Cl}^{-}, \mathrm{SO}_{4}{ }^{2-}$, and $\mathrm{NO}_{3}{ }^{-}$were 102, 13.3, 14.5, and $6.9 \mathrm{mg} / \mathrm{L}$, respectively. $\mathrm{High}^{-} \mathrm{Cl}^{-}$in groundwater was indication of contamination by sewage and seawater intrusion in urban and coastal areas $[8,26]$.

\subsection{Spatial Distribution of Groundwater Quality}

The groundwater quality in the study area was monitored for ten years for the selected water quality parameters. Median values of groundwater quality parameters were used to present the spatial distribution of groundwater quality for each monitoring station (Figure 3). At some monitoring stations, the groundwater seemed to have natural characteristics while, a number of monitoring stations showed the groundwater contamination. Low groundwater $\mathrm{T}\left(<15.8^{\circ} \mathrm{C}\right)$ was predominant in the northern areas, whereas high $\mathrm{T}\left(>15.8^{\circ} \mathrm{C}\right)$ was primarily found in the southern areas. This revealed the effect of air temperature to groundwater temperature, that varies based on high latitude (northern) to low latitude (southern) areas [27]. Spatial distribution of $\mathrm{pH}$ varied from 6 (slightly acidic) to 7.5 (neutral) in 77 out of 97 stations. This range of $\mathrm{pH}$ can be due to the number of reasons including: precipitation water recharge of low alkalinity, leaching of applied fertilizers, industrial activities, and leakage from the abandoned mines [28]. Overall, 50 monitoring stations exhibited EC $>317 \mu \mathrm{S} / \mathrm{cm}$ (median of EC), of which $48 \%$ (24 out of 50) of monitoring stations were located on cropland areas (rice paddies and upland fields) and 22\% (11 out of 50) were located in the residential areas. This showed the influence of applied fertilizers and wastewater to increased contamination of groundwater, as EC reveals the presence of ions in water. Groundwater Eh values showed the opposite pattern to the spatial distribution of groundwater $\mathrm{T}$, as high $\mathrm{Eh}(>302 \mathrm{mV})$ was principally distributed in the northern areas, and low Eh $(<302 \mathrm{mV})$ was predominant in the southern areas. Both $\mathrm{T}$ and Eh were correlated in groundwater. Therefore, because the groundwater is influenced by changing climate, future changes in spatial distribution characteristics of $\mathrm{T}$ and Eh should be carefully monitored.

Among cations, $\mathrm{Ca}^{2+}$ and $\mathrm{Mg}^{2+}$ displayed high values in groundwater at different monitoring stations, based on the natural presence of solids and rocks, especially from plagioclase, dolomite, and gypsum [19]. Spatial distribution of both of these cations in groundwater was dependent on the presence of natural situations [16]. Being responsible for the hardness of water, when present in large quantities, appropriate treatment is required to use groundwater for industrial and domestic use [12]. The high $\mathrm{Na}^{+}$values $(>30 \mathrm{mg} / \mathrm{L})$ were not found in the groundwater of northeastern areas and some central areas of the country. There were number of sources for groundwater high $\mathrm{Na}^{+}$ including: natural deposits from $\mathrm{Na}^{+}$bearing minerals, mixing with surface water contaminated by road salt, leaching from animal wastes, and sewage effluents [29]. Natural sources were more common in northern areas and anthropogenic activities were responsible for high $\mathrm{Na}^{+}$in southern areas. Among major cations, $\mathrm{K}^{+}$concentrations were the lowest in groundwater. Linked to this, $\mathrm{K}^{+}$containing minerals are more resistant to weathering than other minerals because potassium is combined in the form of clay minerals [30].

Among anions, $\mathrm{HCO}_{3}^{-}$was the most abundant ion in groundwater of the study area. Spatial distribution of high $\mathrm{HCO}_{3}{ }^{-}(>102 \mathrm{mg} / \mathrm{L})$ found in the whole area, specifically in the eastern areas, based on the occurrence of natural sources of $\mathrm{HCO}_{3}{ }^{-}$. There were several possible sources of $\mathrm{HCO}_{3}{ }^{-}$in groundwater including: weathering of silicate minerals, presence of calcite and dolomite rocks, corrosion of organic matter which help to produce carbon dioxide, and rainfall [31-33]. Spatial distribution of $\mathrm{Cl}^{-}$in groundwater was predominant in the southwestern areas, especially near the coastal areas. Naturally and anthropogenically, it was attributed to the domestic sewage and seawater intrusion [26,34]. $\mathrm{NaCl}$ is discharged from households as dishwater or excreta, and salty substances flow into the sewer pipe [34]. Groundwater $\mathrm{SO}_{4}{ }^{2-}$ which was the third most abundant anion, showed varying spatial distribution. Lower values of groundwater $\mathrm{SO}_{4}{ }^{2-}$ seem to show the 
absence of such human activities in the area. Groundwater $\mathrm{NO}_{3}{ }^{-}$displayed the most varying spatial distribution and high values $(>10 \mathrm{mg} / \mathrm{L})$ were found in the whole area.
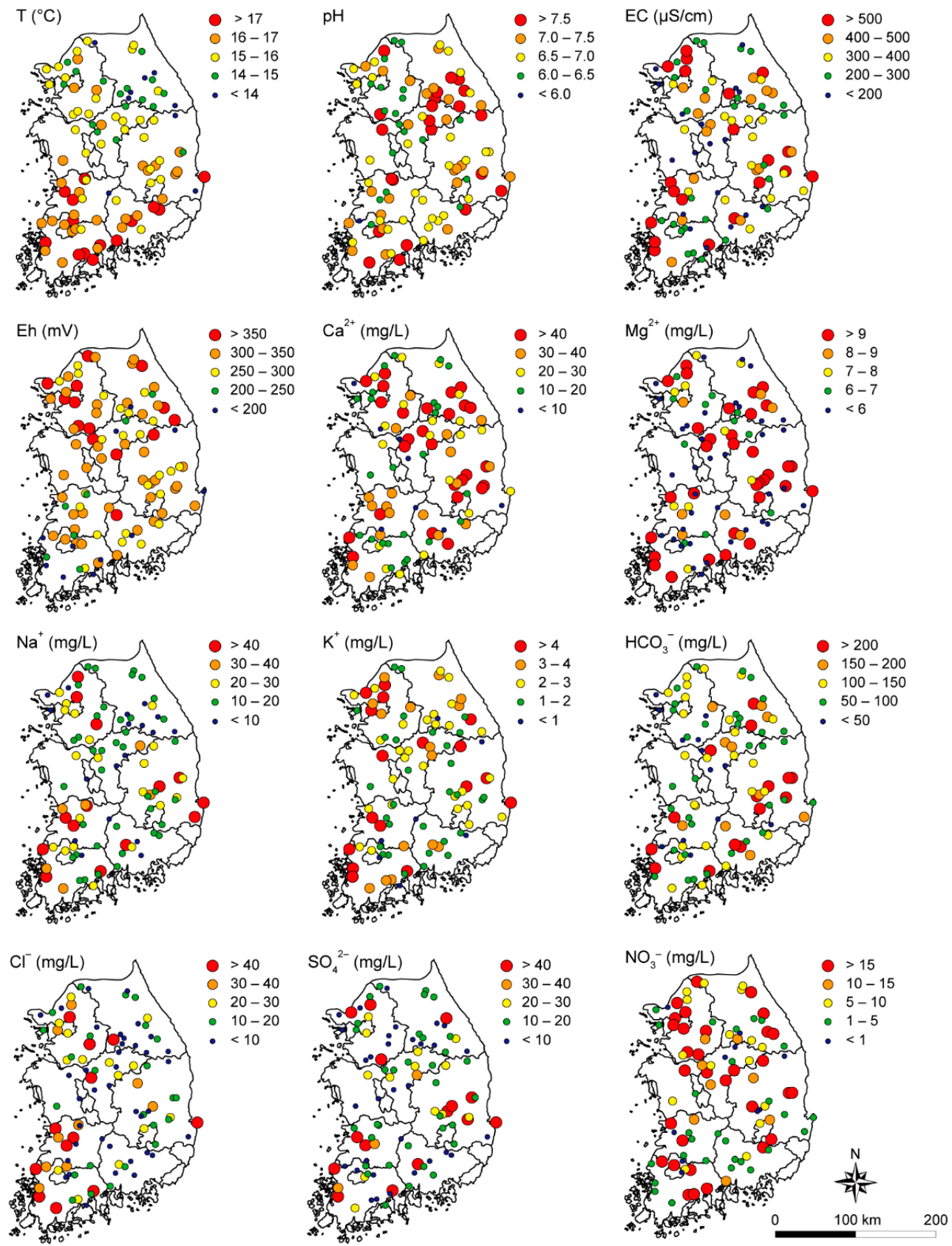

Figure 3. Spatial distribution of hydrochemical parameters at all monitoring stations $(n=97)$ from 2008 to 2017.

\subsection{Temporal Trend of Groundwater Quality}

Statistical analyses were done for the groundwater quality parameters. Box-whisker plots of the 12 parameters were generated to see the data variations during the studied time period (Figure 4). All parameters showed small to large variations in values monitored in different years. The average coefficient of variance (CV), which shows the extent of variation in particular dataset, for the mentioned groundwater quality parameters was 3.57 (Table 1). Six parameters-EC, $\mathrm{Ca}^{2+}$, $\mathrm{Mg}^{2+}, \mathrm{Na}^{+}, \mathrm{K}^{+}$, and $\mathrm{Cl}^{-}$-had high $\mathrm{CV}(>3.57)$ and showed higher variance in different years (Figure 4). Other parameters- $\mathrm{T}, \mathrm{pH}$, and $\mathrm{Eh}-$ had fluctuating values with no major variance in the data values 
during the studied period. However, $\mathrm{NO}_{3}{ }^{-}$revealed a clear decrease in the variance after 2008 . This change seems to be affected by the implementation of restricted fertilizer amounts in agricultural areas and sustainable agricultural activities [35]. Groundwater quality parameters with high CV have displayed longer boxes with lower minimum and higher maximum values. In addition, those six parameters were considered as the indicators of groundwater contamination by seawater intrusion [36]. In 2009 and onwards, those parameters showed an increase in the variance which might be linked to the installation of Pohang monitoring station in coastal area in the same year 2009.
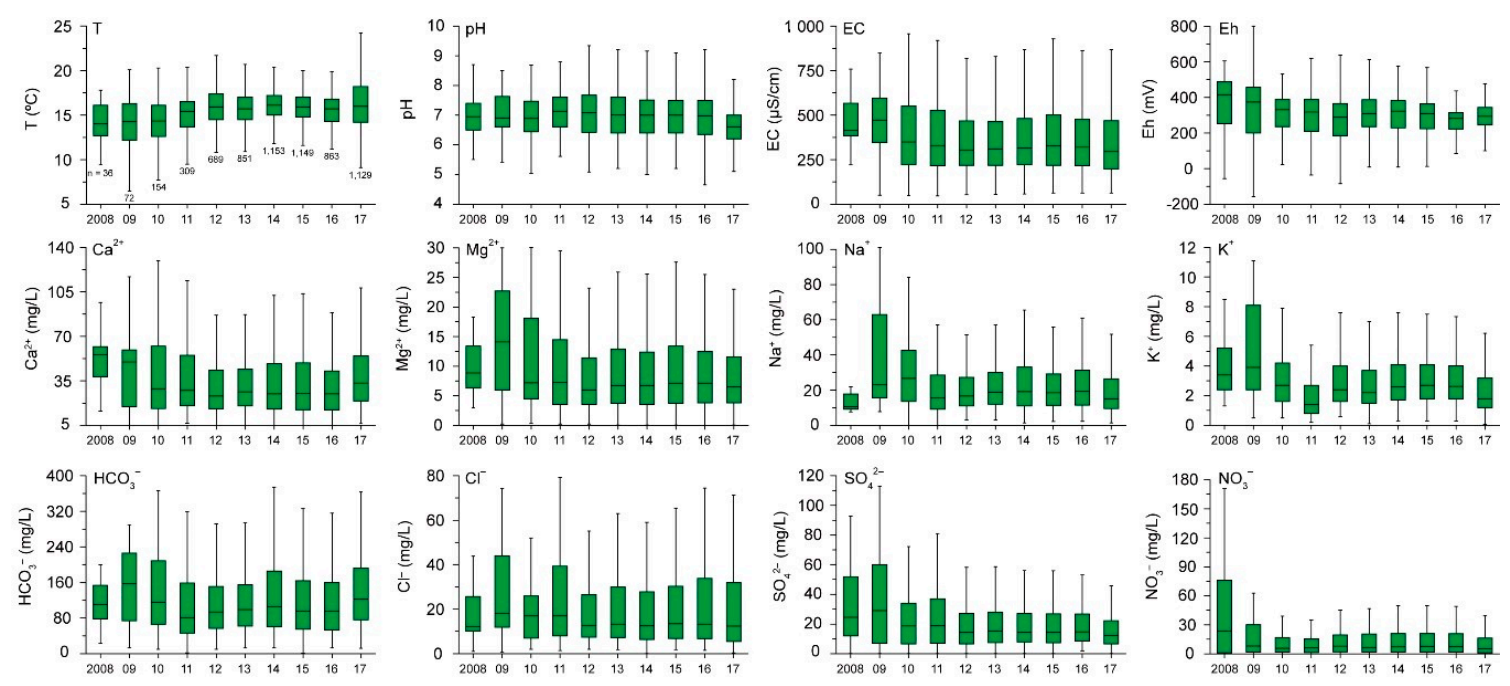

Figure 4. Box-whisker plots of groundwater quality parameters monitored for 2008-2017 ( $\mathrm{n}=6405)$.

For trend analysis, linear regression slopes were applied to the decadal data of groundwater quality parameters (Figure 5). Percentage of groundwater data with increasing and decreasing trends was presented in Table 2. Among water quality parameters, $\mathrm{T}, \mathrm{EC}, \mathrm{Ca}^{2+}, \mathrm{Mg}^{2+}, \mathrm{HCO}_{3}{ }^{-}$, and $\mathrm{Cl}^{-}$ had dominating percentages for the increasing trends while, for $\mathrm{pH}, \mathrm{Eh}, \mathrm{Na}^{+}, \mathrm{K}^{+}, \mathrm{SO}_{4}{ }^{2-}$, and $\mathrm{NO}_{3}{ }^{-}$, a decreasing trend dominated over the increasing trend. The countrywide spatial distribution of temporal trend (linear regression slope results) of groundwater quality parameters is given in Figure 5 . For groundwater $\mathrm{T}$, an increasing trend was observed in the northeast and southwest, whereas a decreasing trend was found in the northwest. Air temperature was steadily increasing due to changing climate which can increase the groundwater T. Statistically, the $\mathrm{pH}$ exhibited predominant decreasing trend throughout the national scale. However, the median of variation is -0.02 (Table 2), and it seems to be changed little.

Table 2. Summary of linear regression slopes (unit of each parameter/a quarter) for 2008-2017 (number of slopes for each parameter $=289$ ).

\begin{tabular}{|c|c|c|c|c|c|c|}
\hline Parameters & Maximum & Minimum & Mean & Median & Increasing (\%) & Decreasing (\%) \\
\hline $\mathrm{T}$ & 0.3 & -0.5 & 0.01 & 0.02 & 63 & 37 \\
\hline $\mathrm{pH}$ & 0.07 & -0.2 & -0.03 & -0.02 & 19 & 81 \\
\hline $\mathrm{EC}$ & 97.3 & -379 & -0.7 & 0.7 & 57 & 43 \\
\hline Eh & 15.2 & -23.1 & -1.4 & -1.3 & 37 & 63 \\
\hline $\mathrm{Ca}^{2+}$ & 16.8 & -86.7 & 0.2 & 0.3 & 72 & 28 \\
\hline $\mathrm{Mg}^{2+}$ & 4.8 & -34.9 & -0.09 & 0.03 & 61 & 39 \\
\hline $\mathrm{Na}^{+}$ & 46.9 & -72.7 & 0.1 & -0.05 & 41 & 59 \\
\hline $\mathrm{K}^{+}$ & 1.5 & -12.9 & -0.06 & -0.01 & 40 & 60 \\
\hline $\mathrm{HCO}_{3}{ }^{-}$ & 11.0 & -8.9 & 0.9 & 0.7 & 73 & 27 \\
\hline $\mathrm{Cl}^{-}$ & 70.7 & -375 & -0.2 & 0.01 & 52 & 48 \\
\hline $\mathrm{SO}_{4}^{2-}$ & 6.4 & -31.6 & -0.6 & -0.1 & 34 & 66 \\
\hline $\mathrm{NO}_{3}^{-}$ & 2.1 & -8.5 & -0.2 & -0.05 & 33 & 67 \\
\hline
\end{tabular}



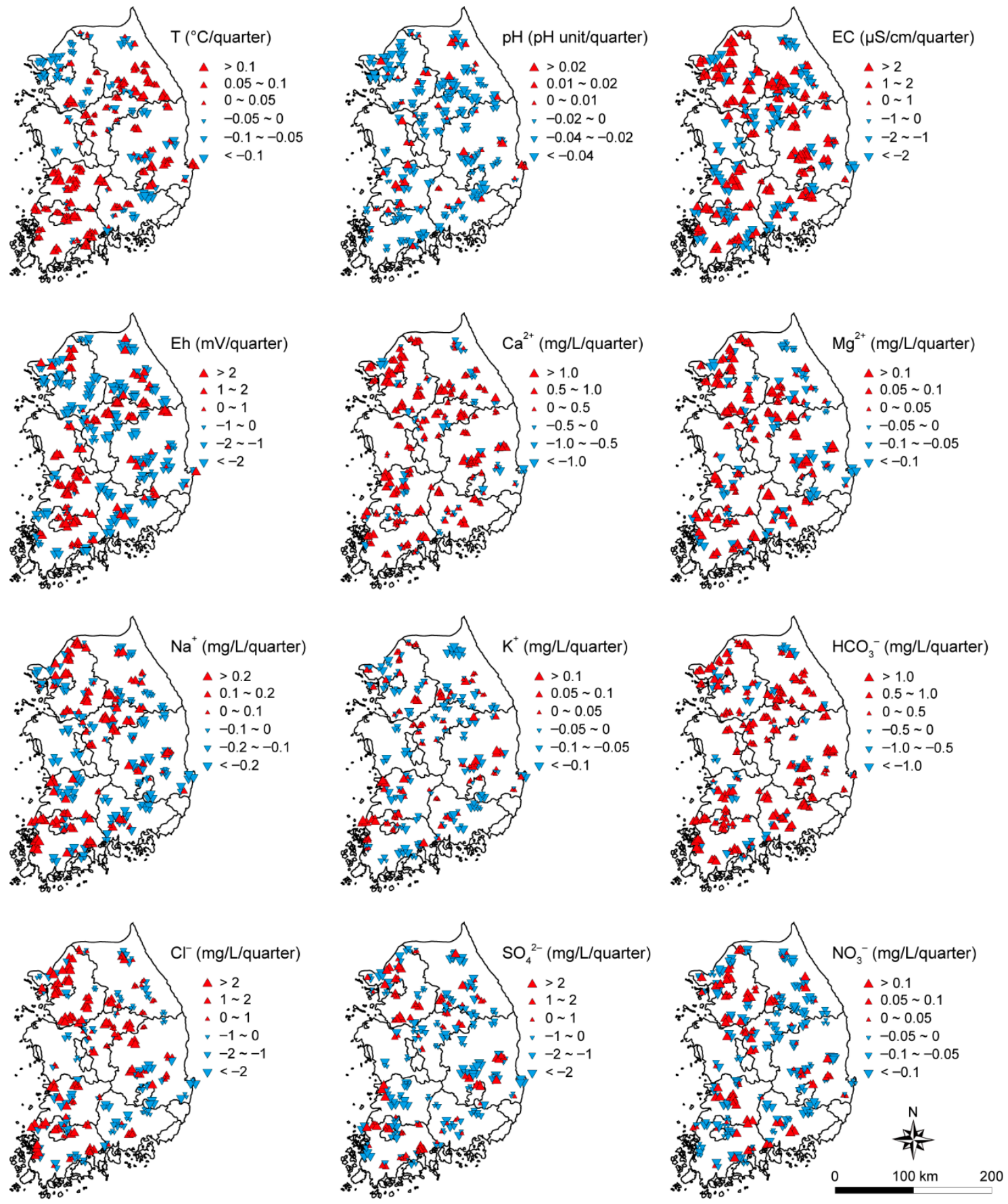

Figure 5. Distribution of linear regression slopes for each hydrochemical parameter at all monitoring stations $(n=289)$ for the period of 2008-2017.

For groundwater ions; $\mathrm{Ca}^{2+}$ and $\mathrm{HCO}_{3}{ }^{-}$, an increasing trend was observed throughout the country while, for $\mathrm{Cl}^{-}$the increasing trend was observed in western region. On the other hand, $\mathrm{SO}_{4}{ }^{2-}$ and $\mathrm{NO}_{3}{ }^{-}$presented dominant decreasing trend throughout the country, except some western regions with an increasing trend. In a separate study [37], groundwater EC fluctuated within 240-320 $\mu \mathrm{S} / \mathrm{cm}$ from 2008 to 2014 at 213 monitoring wells of NGMN. Lee et al. [17] said that groundwater $\mathrm{NO}_{3}{ }^{-}$showed the decreasing trends over the analysis period of 13 years (2001-2013) in 1628 out of total 2939 wells. In Korea, there are few studies on temporal variations in groundwater quality, and more attention is needed on it. 


\subsection{Major Factors Controlling Spatiotemporal Distribution of Groundwater Quality}

\subsubsection{Fertilizers Application}

Generally, intensive agricultural activities in the croplands, are the source of groundwater contamination in the surrounding areas. In Korea, approximately, 1,400,000 ha $\left(14,000 \mathrm{~km}^{2}\right)$ of the area consists of agricultural crops of rice and upland fields including fruits, outdoor vegetables, greenhouse, and medicinal crops [38]. Overuse of chemical fertilizers in these croplands is a common practice to increase the crop productivity for economic benefits. Chemical fertilizers normally used in the croplands in 2016 were: nitrogen (55\%), potassium (25\%), and phosphorus (20\%) fertilizers [39]. $\mathrm{NO}_{3}{ }^{-}$from the applied nitrogen fertilizers can infiltrate from agricultural soil to groundwater with precipitation and irrigation water, causing groundwater $\mathrm{NO}_{3}{ }^{-}$contamination [17]. The $\mathrm{NO}_{3}{ }^{-}$contamination has potential to pose a health risk to children, when used for drinking purpose. Additionally, this can lead to eutrophication and green algal blooms when discharged to surface water bodies [39]. The overall application of these fertilizers has been reduced in 2016 as compared to 2008. Still, the applied amounts exceeded the Korean standard limits of fertilizers application in 2016 [38].

Three main water quality parameters are considered as the indicators for groundwater contamination when present in excessive amounts. Table 3 presented the mean concentrations of main parameters: $\mathrm{NO}_{3}{ }^{-}, \mathrm{Cl}^{-}$, and $\mathrm{Na}^{+}$in groundwater from the monitoring stations located in upland fields, rice paddies, forests, and residential areas. The mean $\mathrm{NO}_{3}{ }^{-}$concentration in groundwater of the country was $16.8 \mathrm{mg} / \mathrm{L}$ (Table 1). It was higher by $5.4 \mathrm{mg} / \mathrm{L}$ (mean $=22.2 \mathrm{mg} / \mathrm{L}$; Table 3) in the groundwater of upland fields. However, the value of rice paddies was similar to that of the study area $($ mean $=16.6 \mathrm{mg} / \mathrm{L})$. The upland fields include fruits, vegetables, greenhouse, and medicinal crops and hence received more amounts of nitrogen fertilizers collectively than the crop of rice paddies. Forest and residential areas showed lower mean values for groundwater $\mathrm{NO}_{3}{ }^{-}$than the mean of study area.

Table 3. Mean concentrations of three parameters $\left(\mathrm{NO}_{3}{ }^{-}, \mathrm{Cl}^{-}\right.$, and $\left.\mathrm{Na}^{+}\right)$in groundwater from monitoring stations located in upland fields, rice paddies, forests, and residential areas. During the total duration of study, the numbers of data in the upland fields, rice paddies, forests, and residential areas were 1501, 1773, 2184, and 947, respectively.

\begin{tabular}{ccccc}
\hline \multirow{2}{*}{ Parameters } & \multicolumn{4}{c}{ Land Use } \\
\cline { 2 - 5 } & Upland Field & Rice Paddy & Forest & Residential Area \\
\hline $\mathrm{NO}_{3}{ }^{-}(\mathrm{mg} / \mathrm{L})$ & 22.2 & 16.6 & 13.4 & 16.2 \\
$\mathrm{Cl}^{-}(\mathrm{mg} / \mathrm{L})$ & 19.4 & 297.3 & 27.8 & 705.3 \\
$\mathrm{Na}^{+}(\mathrm{mg} / \mathrm{L})$ & 24.2 & 144.1 & 29.6 & 298.4 \\
\hline
\end{tabular}

The Korean application standard for nitrogen fertilizer on upland fields crops are greater than those on growing rice by $5.1 \mathrm{~kg}$ per $1000 \mathrm{~m}^{2}(=10 \mathrm{a})$ [38]. Additionally, the irrigation of rice paddies, in contrast with upland fields irrigations that does not store water, is to store ponded water within $7 \mathrm{~cm}$ depth from bottom of rice paddy to supply soil moisture and nutrient for rice [40]. Therefore, more $\mathrm{NO}_{3}{ }^{-}$can leach down to the groundwater of upland fields than that of rice paddies. Additionally, $\mathrm{NO}_{3}{ }^{-}$concentration in groundwater of residential areas was approximately equal to that of rice paddies (Table 3). This was because groundwater $\mathrm{NO}_{3}{ }^{-}$originated not only from agricultural activities but also from domestic activities in the residential areas [34]. Meanwhile, the Korean groundwater standards of domestic and agricultural water for $\mathrm{NO}_{3}{ }^{-}$is $88.6 \mathrm{mg} / \mathrm{L}\left(\mathrm{NO}_{3}{ }^{-}-\mathrm{N}\right.$ is $\left.20 \mathrm{mg} / \mathrm{L}\right)$ [41]. The mean $\mathrm{NO}_{3}{ }^{-}$ concentration of groundwater exceeded the standards at four monitoring wells of the study area. 


\subsubsection{Sewage Leakage}

Some ions are considered to be indicators of water contamination from domestic activities, i.e., $\mathrm{Cl}^{-}$and $\mathrm{Na}^{+}$ions [34]. In groundwater, $\mathrm{Cl}^{-}$originated from dishwater, human excreta, household product use, road salt use, and wastewater chlorination [42]. High $\mathrm{Cl}^{-}$in groundwater can affect the taste of drinking water [43]. In the studied area, median values of $\mathrm{Cl}^{-}$and $\mathrm{Na}^{+}$were higher in the groundwater from monitoring stations located in the residential areas, than in other land uses (Table 3). Mean $\mathrm{Cl}^{-}$in groundwater from residential areas was $705.3 \mathrm{mg} / \mathrm{L}$, which was the highest mean of all four land uses, and greater than the mean of the entire study area by $504.3 \mathrm{mg} / \mathrm{L}$ (Tables 1 and 3). Similarly, mean $\mathrm{Na}^{+}$in groundwater from residential area was $298.4 \mathrm{mg} / \mathrm{L}$ (Table 3), significantly higher than the mean groundwater $\mathrm{Na}^{+}$from other land uses. Domestic sewage discharged from household chores (cleaning, dishwashing, laundry, and human excrement) in populated residential areas were considered as the main factors for high $\mathrm{Cl}^{-}$and $\mathrm{Na}^{+}$ions in groundwater of residential areas [42].

Not only had the domestic activities, some faults in sewage system of residential areas caused the groundwater contamination. Domestic sewage transported to septic tanks via sewer pipelines, any kind of damage or leak in sewer pipeline might result in leach down of sewage to groundwater, causing groundwater contamination [44]. In Korea, the total length of installed sewer pipelines was $156,257 \mathrm{~km}$ in 2018, which was approximately four times of circumference of the Earth (40,000 km) [44]. Among the pipelines, $66,334 \mathrm{~km}(42 \%)$ length of pipelines were installed 20 years ago, considered old and shabby. Additionally, 31,125 km (47\%) of total shabby pipelines were distributed in urban areas (12,697 km in Gyeonggi-do, $7432 \mathrm{~km}$ in Seoul, $6688 \mathrm{~km}$ in Busan, and $4308 \mathrm{~km}$ in Daegu) [44]. Therefore, domestic activities in the urban areas were the main controlling factor for groundwater ionic contamination (high $\mathrm{Cl}^{-}$and $\mathrm{Na}^{+}$). The Korean groundwater standards of domestic and agricultural water for $\mathrm{Cl}^{-}$is $250 \mathrm{mg} / \mathrm{L}$ [41]. The mean groundwater $\mathrm{Cl}^{-}$exceeded the standards at 11 monitoring wells of the study area.

\subsubsection{Seawater Intrusion}

Korea is land bounded country from one side and is surrounded by sea from the other three sides (Figure 1). Aquifers in coastal areas are affected by seawater intrusion as a result of anthropogenic activities in the coastal areas [26]. Among 97 countrywide GQMN stations, 15 monitoring stations were located within $10 \mathrm{~km}$ of the sea, considered as the coastal area (Table 4). Six important groundwater quality parameters $\left(\mathrm{Cl}^{-}, \mathrm{Na}^{+}, \mathrm{Ca}^{2+}, \mathrm{Mg}^{2+}, \mathrm{K}^{+}\right.$, and EC) were selected to examine the ionic contamination in coastal areas. As these ions parameters can indicate the effect of seawater intrusion to groundwater, as a result of anthropogenic activities [6,26]. The groundwater of the 15 stations in coastal areas showed considerably higher values (up to 26 times for $\mathrm{Cl}^{-}$) than those in the inland areas (Table 4). These high values were the indication of seawater mixing [36].

Table 4. Mean values of six groundwater quality parameters observed in monitoring stations located in the coastal areas (areas within the $10 \mathrm{~km}$ from sea), and in the inland areas of Korea, during studied period.

\begin{tabular}{ccc}
\hline Parameters & $\begin{array}{c}\text { Mean } \\
\text { (Coastal Area, } \mathbf{n = 1 5 )}\end{array}$ & $\begin{array}{c}\text { Mean } \\
\text { (Inland Area, } \mathbf{n}=82)\end{array}$ \\
\hline $\mathrm{Cl}^{-}(\mathrm{mg} / \mathrm{L})$ & 457.4 & 17.9 \\
$\mathrm{Na}^{+}(\mathrm{mg} / \mathrm{L})$ & 280.9 & 20.5 \\
$\mathrm{Ca}^{2+}(\mathrm{mg} / \mathrm{L})$ & 40.1 & 33.1 \\
$\mathrm{Mg}^{2+}(\mathrm{mg} / \mathrm{L})$ & 26.3 & 8.8 \\
$\mathrm{~K}^{+}(\mathrm{mg} / \mathrm{L})$ & 9.5 & 2.7 \\
$\mathrm{EC}(\mu \mathrm{S} / \mathrm{cm})$ & 1445 & 348 \\
\hline
\end{tabular}

The maximum observed values of these parameters led to the calculation of the mean higher than the median (Table 1). Especially, high $\mathrm{Cl}^{-}$in the groundwater of the coastal area might be due to 
the natural process of evapotranspiration, or anthropogenic over-pumping of groundwater resulting in lower water levels and seawater intrusion to refill the groundwater aquifer [26,36]. Other than $\mathrm{Cl}^{-}$, groundwater $\mathrm{Ca}^{2+}$ was high $(>1000 \mathrm{mg} / \mathrm{L})$ in three monitoring stations, groundwater $\mathrm{Mg}^{2+}$ was high $(>1000 \mathrm{mg} / \mathrm{L})$ in two monitoring stations, and groundwater $\mathrm{Na}^{+}$was high $(>1000 \mathrm{mg} / \mathrm{L})$ in four monitoring stations, located in the coastal area. These high values in groundwater were the indicator of brine mixing [25]. Therefore, groundwater contamination in coastal area was controlled mainly by the natural and anthropogenic factors aggravating the seawater intrusion to groundwater aquifer

\subsection{Mechanism for Controlling the Hydrochemistry of Groundwater}

Changes in land use may cause variations in the groundwater quality of the country. Anthropogenic influence on groundwater quality is described in Sections 3.4.1-3.4.3, representing high ionic concentrations in particular land use areas. Meanwhile, Gibbs diagrams provide basic information on natural factors that influence hydrogeochemical evolution [45]. The evolution starts from the $\mathrm{Ca}-\mathrm{HCO}_{3}$ water type because most of geology constituting aquifers contain silicate or carbonate minerals [46]. Sometimes the hydrochemistry can be affected by saline water (seawater, coastal river, and evaporative lakes) [47]. Thus, water samples shown in the upper right of the diagram are indicative of this effect. Meanwhile, when precipitation water infiltrates into groundwater, thus water is plotted at the lower part of the diagram because dilution and mixing of the precipitation and groundwater occur, and the TDS value becomes low [46].

To identify the mechanism controlling the hydrochemistry of groundwater, Gibbs diagram was used (Figure 6). The mechanisms can be inferred from three end members. End member 1 had low TDS $<10 \mathrm{mg} / \mathrm{L}$ and high values for $\mathrm{Na}^{+} /\left(\mathrm{Na}^{+}+\mathrm{Ca}^{2+}\right)$ and $\mathrm{Cl}^{-} /\left(\mathrm{Cl}^{-}+\mathrm{HCO}_{3}{ }^{-}\right)$, ranging from 0.5 to 1 , positioned in the lower right portion revealed the precipitation dominance. There was no sample found in this portion. End member 2 had intermediate TDS ranged $50-950 \mathrm{mg} / \mathrm{L}$, and values for $\mathrm{Na}^{+} /\left(\mathrm{Na}^{+}+\mathrm{Ca}^{2+}\right)$ and $\mathrm{Cl}^{-} /\left(\mathrm{Cl}^{-}+\mathrm{HCO}_{3}{ }^{-}\right)$, ranging from $0.03-0.93$ and $0.01-0.82$, respectively. The samples were placed in the left side of the middle portion, indicated the rock dominance. The results of 96 monitoring stations were placed in rock dominance portion indicating the mechanism of water-rock interaction. Endmember 3 had high TDS $>10,000 \mathrm{mg} / \mathrm{L}$ and high values for $\mathrm{Na}^{+} /\left(\mathrm{Na}^{+}+\mathrm{Ca}^{2+}\right)$ and $\mathrm{Cl}^{-} /\left(\mathrm{Cl}^{-}+\mathrm{HCO}_{3}{ }^{-}\right)$ were 0.94 and 0.96 , respectively. Only one monitoring station got placed in the top right portion, indicating evaporation dominance.
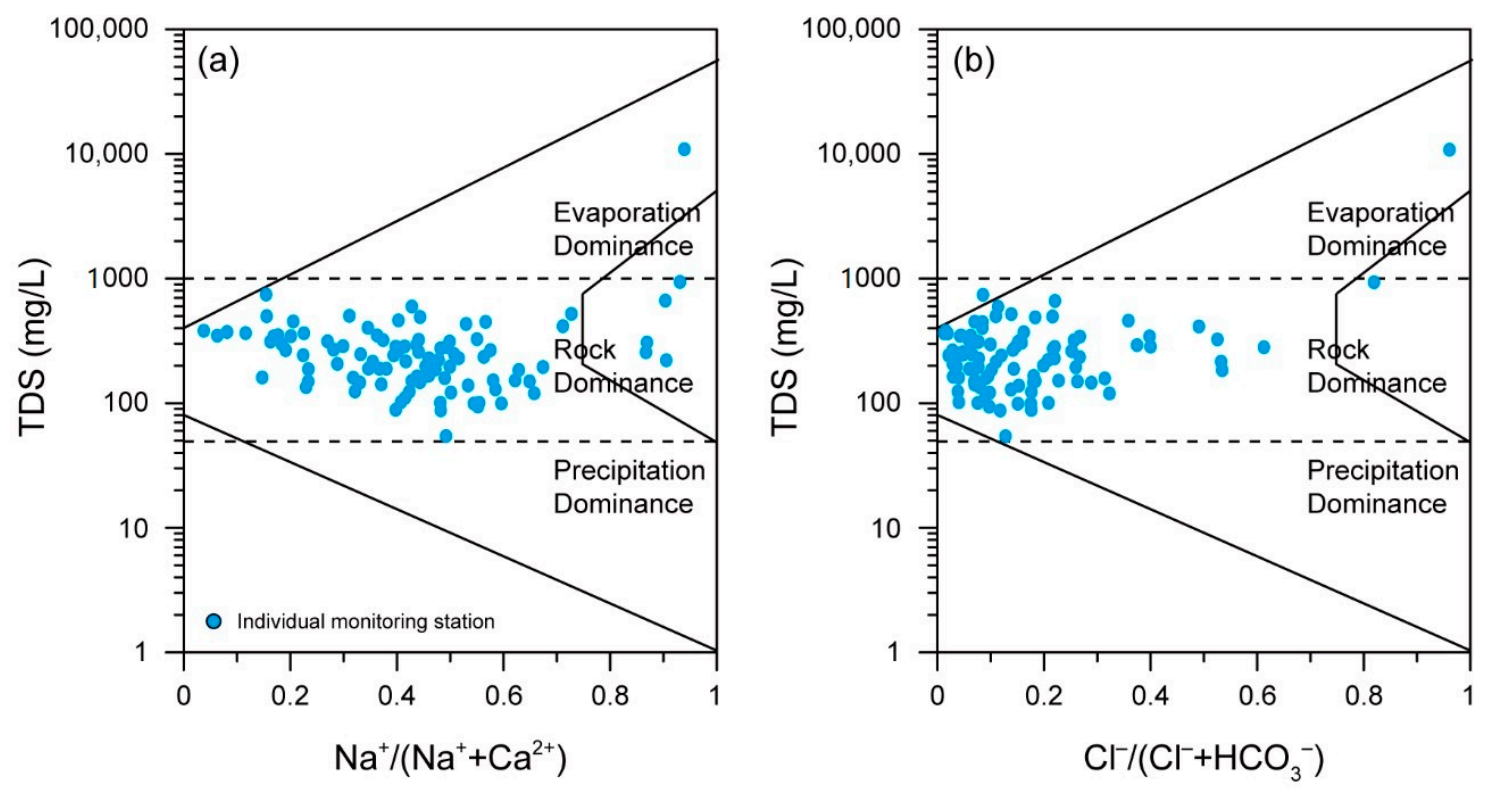

Figure 6. Gibbs diagrams showing the ratio of TDS and $\mathrm{Na}^{+} /\left(\mathrm{Na}^{+}+\mathrm{Ca}^{2+}\right)$ or $\mathrm{Cl}^{-} /\left(\mathrm{Cl}^{-}+\mathrm{HCO}_{3}^{-}\right)$and indicating mechanisms controlling the groundwater chemistry in the study area $(n=97)$. 
Results from all monitoring stations $(\mathrm{n}=97)$ illustrated the dominancy of geogenic factors in both portions of the Gibbs diagram: rock and evaporation dominance. Rock dominance as the controlling mechanism for hydrochemistry of groundwater indicated that groundwater was interacting with rocks and resulted in rock weathering [12]. Moreover, evaporation dominance evidenced the major role of evaporation-crystallization mechanism in geological settings as a major controlling factor of groundwater hydrochemistry [45]. Sidhu et al. [48] showed that chemical weathering of the minerals composing rocks affects the groundwater chemistry, and the hydrochemical characteristics are not related to well depths.

\subsection{Statistical Verification of Ions Co-Occurrence and Sources}

Correlation matrix was used as a statistical tool to determine the relationship between two water quality parameters for estimating the degree of dependency of one parameter to the other [49]. Pearson correlation was used for this study and represented in Table 5. EC had a positive correlation with $\mathrm{Ca}^{2+}, \mathrm{Mg}^{2+}, \mathrm{Na}^{+}, \mathrm{Cl}^{-}$, and $\mathrm{SO}_{4}{ }^{2-}$ in groundwater, indicating increased contamination [31]. $\mathrm{Ca}^{2+}$ and $\mathrm{Mg}^{2+}$ showed a positive correlation with $\mathrm{Na}^{+}$and $\mathrm{Cl}^{-}$in groundwater. $\mathrm{Na}^{+}$had positive correlation with $\mathrm{Cl}^{-}$and $\mathrm{SO}_{4}{ }^{2-}$ in groundwater. Additionally, $\mathrm{Cl}^{-}$showed positive correlation for $\mathrm{SO}_{4}{ }^{2-}$ in groundwater. The strong positive correlations among water quality parameters exposed the weathering of carbonate rocks, evaporites, soil salts, and interaction of halite with groundwater as the common sources of increase in values of these ion in groundwater [45]. Other ions, $\mathrm{NO}_{3}{ }^{-}$and $\mathrm{K}^{+}$, did not have a strong correlation with other parameters.

Table 5. Pearson correlation coefficient showing the extent of association between groundwater quality parameters. Strong correlations are shown in bold.

\begin{tabular}{|c|c|c|c|c|c|c|c|c|c|c|c|c|}
\hline Parameters & $T$ & $\mathrm{pH}$ & EC & Eh & $\mathrm{Ca}^{2+}$ & $\mathrm{Mg}^{2+}$ & $\mathrm{Na}^{+}$ & $\mathrm{K}^{+}$ & $\mathrm{HCO}_{3}{ }^{-}$ & $\mathrm{Cl}^{-}$ & $\mathrm{SO}_{4}{ }^{2-}$ & $\mathrm{NO}_{3}{ }^{-}$ \\
\hline $\mathrm{T}$ & 1 & & & & & & & & & & & \\
\hline $\mathrm{pH}$ & -0.03 * & 1 & & & & & & & & & & \\
\hline EC & $0.06^{* *}$ & 0.02 & 1 & & & & & & & & & \\
\hline $\mathrm{Ca}^{2+}$ & $0.05^{* *}$ & 0.00 & $0.88^{* *}$ & $-0.16^{* *}$ & 1 & & & & & & & \\
\hline $\mathrm{Mg}^{2+}$ & $0.06^{* *}$ & 0.01 & $0.90 * *$ & $-0.17^{* *}$ & $0.95^{* *}$ & 1 & & & & & & \\
\hline $\mathrm{Na}^{+}$ & $0.08^{* *}$ & 0.02 & $0.93 * *$ & $-0.21 * *$ & $0.87^{* *}$ & $0.89 * *$ & 1 & & & & & \\
\hline $\mathrm{Cl}^{-}$ & $0.07^{* *}$ & 0.01 & $0.93^{* *}$ & $-0.18^{* *}$ & $0.94^{* *}$ & $0.95 * *$ & $0.96^{* *}$ & 0.30 ** & $0.04^{* *}$ & 1 & & \\
\hline $\mathrm{SO}_{4}^{2-}$ & $0.08^{* *}$ & 0.01 & $0.83^{* *}$ & $-0.20 * *$ & $0.74^{* *}$ & $0.76^{* *}$ & $0.85^{* *}$ & $0.33^{* *}$ & 0.23 ** & $0.81 * *$ & 1 & \\
\hline $\mathrm{NO}_{3}{ }^{-}$ & $-0.08^{* *}$ & $-0.22 * *$ & $-0.03 * *$ & $0.20 * *$ & -0.01 & $-0.04 * *$ & $-0.06^{* *}$ & 0.00 & $-0.18^{* *}$ & $-0.05^{* *}$ & $-0.03 * *$ & 1 \\
\hline
\end{tabular}

Another statistical technique, PCA, was applied to the water quality data to reduce dimensionality of interrelated parameters [12]. Statistical PCA analysis was applied to groundwater quality parameters: $\mathrm{T}, \mathrm{pH}, \mathrm{EC}, \mathrm{Eh}, \mathrm{Ca}^{2+}, \mathrm{Mg}^{2+}, \mathrm{Na}^{+}, \mathrm{K}^{+}, \mathrm{HCO}_{3}{ }^{-}, \mathrm{Cl}^{-}, \mathrm{SO}_{4}{ }^{2-}$, and $\mathrm{NO}_{3}{ }^{-}$monitored during the studied period, to identify the parameters with the greatest clarifying power that control the hydrochemistry of the groundwater. The results were obtained in the form of principal components (PCs), having eigenvalues $>1$ and explained the different variances (Table 6).

It was indicated that three components explained $69.23 \%$ of the total variance. PC1 explained $46.56 \%$ of variance, had positive loadings with $\mathrm{EC}, \mathrm{Ca}^{2+}, \mathrm{Mg}^{2+}, \mathrm{Na}^{+}, \mathrm{Cl}^{-}$, and $\mathrm{SO}_{4}{ }^{2-}$ indicated mineral dissolution or carbonate rock weathering as the major source of these contents, along with concurrence of evaporite dissolution. PC2 explained $14.19 \%$ of variance did not show strong loadings with the ions. PC 3 explained $8.48 \%$ of variance had positive loading with T of groundwater. Figure 7 illustrated more explanatory loadings and interlinkages of $\mathrm{PC} 1$ and $\mathrm{PC} 2$, the more percentage of variance.

For better understanding, a PCA plot was generated using PC1 and PC2, which have explained $60.75 \%$ of the total data variance. Parameters located on one side of plot show a positive correlation to each other and a negative correlation to parameters located on the other side of the plot, and vice versa. Parameters in the upper right side of the PCA plot were more enriched with EC, $\mathrm{Ca}^{2+}, \mathrm{Mg}^{2+}$, $\mathrm{Na}^{+}, \mathrm{K}^{+}$, and $\mathrm{Cl}^{-}$which had positive loadings (correlation) for both $\mathrm{PC} 1$ and $\mathrm{PC} 2$, while $\mathrm{SO}_{4}{ }^{2-}$ had 
positive loading for PC1 and negative loading for PC2. The colocation of these parameters verified geological weathering of minerals and evaporite dissolution as the dominating sources of these ions [50]. The bottom right side of PCA plot was enriched with $\mathrm{T}, \mathrm{pH}$, and $\mathrm{HCO}_{3}{ }^{-}$, which had positive loadings for PC1 and negative loading for PC2. The sources of these parameters might also be geological and their presence can influence the amounts of other ions in groundwater. The upper left side of PCA plot had Eh and $\mathrm{NO}_{3}{ }^{-}$which had negative loadings for $\mathrm{PC} 1$ and positive loadings for PC2. The colocation of these parameters identified inputs from anthropogenic activities and oxidized environment promoted nitrification in the groundwater as the major sources of these ions in groundwater [51].

Table 6. Results of principal component analysis for groundwater quality parameters.

\begin{tabular}{cccc}
\hline Parameters & PC1 & PC2 & PC3 \\
\hline $\mathrm{T}$ & 0.09 & -0.21 & 0.92 \\
$\mathrm{pH}$ & 0.04 & -0.69 & -0.35 \\
$\mathrm{EC}$ & 0.96 & 0.06 & -0.01 \\
$\mathrm{Eh}$ & -0.24 & 0.65 & -0.04 \\
$\mathrm{Ca}^{2+}$ & 0.94 & 0.10 & -0.03 \\
$\mathrm{Mg}^{2+}$ & 0.95 & 0.08 & -0.01 \\
$\mathrm{Na}^{+}$ & 0.96 & 0.03 & 0.03 \\
$\mathrm{~K}^{+}$ & 0.37 & 0.03 & -0.18 \\
$\mathrm{HCO}_{3}{ }^{-}$ & 0.14 & -0.63 & -0.03 \\
$\mathrm{Cl}^{-}$ & 0.98 & 0.09 & 0.00 \\
$\mathrm{SO}_{4}{ }^{2-}$ & 0.88 & -0.03 & 0.01 \\
$\mathrm{NO}_{3}{ }^{-}$ & -0.06 & 0.58 & -0.06 \\
Eigenvalues & 5.59 & 1.70 & 1.02 \\
Variance (\%) & 46.56 & 14.19 & 8.48 \\
Cumulative $(\%)$ & 46.56 & 60.75 & 69.23 \\
\hline
\end{tabular}

Eigenvector loadings (axes PC1 and PC2 $=60.75 \%$ )

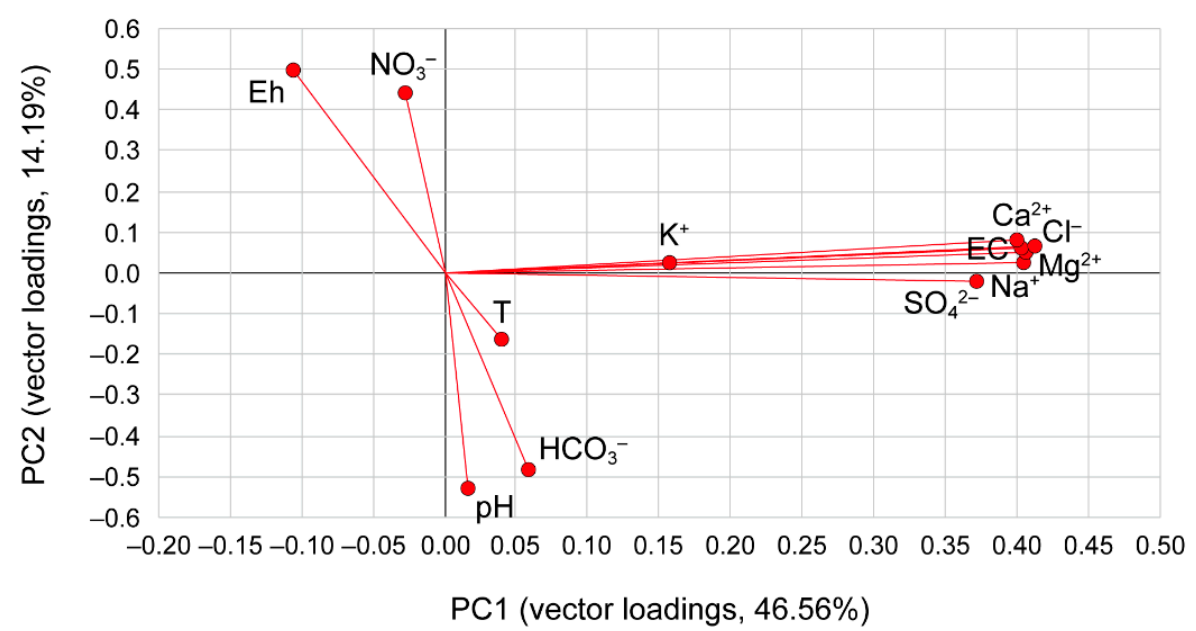

Figure 7. Principal component analysis plot for groundwater quality parameters.

\section{Conclusions}

Spatial distribution of groundwater quality parameters varied through the study area. Occurrence of high values of some parameters was linked to both anthropogenic and natural sources, mainly based on the agricultural and domestic activities, seawater intrusion.

- Six parameters; $\mathrm{T}, \mathrm{EC}, \mathrm{Ca}^{2+}, \mathrm{Mg}^{2+}, \mathrm{HCO}_{3}{ }^{-}$, and $\mathrm{Cl}^{-}$had dominant increasing trends in groundwater during the studied period, revealing the effect of natural and anthropogenic factors. Other parameters, $\mathrm{pH}, \mathrm{Eh}, \mathrm{Na}^{+}, \mathrm{K}^{+}, \mathrm{SO}_{4}{ }^{2-}$, and $\mathrm{NO}_{3}{ }^{-}$showed dominant decreasing trends over time. 
- Among land uses, upland fields had the highest mean value for groundwater $\mathrm{NO}_{3}{ }^{-}(22.2 \mathrm{mg} / \mathrm{L})$, confirming that many fertilizers were applied to upland fields. Thus, agricultural activities were the main controlling factor of groundwater $\mathrm{NO}_{3}{ }^{-}$contamination in agricultural areas.

- In residential areas, $\mathrm{Cl}^{-}$and $\mathrm{Na}^{+}$had high mean values in groundwater of $705.3 \mathrm{mg} / \mathrm{L}$ and $298.4 \mathrm{mg} / \mathrm{L}$, respectively. Thus, domestic activities were the controlling factor of groundwater $\mathrm{Cl}^{-}$ and $\mathrm{Na}^{+}$contamination in residential areas.

- Some monitoring wells exceeded the Korean drinking water standards for $\mathrm{NO}_{3}{ }^{-}$and $\mathrm{Cl}^{-}$. The contamination derived from human activities can be sufficiently reduced by effective active measures. Therefore, the government has to strengthen corresponding regulations in order to minimize deterioration of groundwater quality.

- $\quad \mathrm{Mean}^{-}(457.4 \mathrm{mg} / \mathrm{L})$ of 15 monitoring stations in coastal areas was much higher than that of the monitoring stations in inland. Seawater intrusion naturally or as a result of groundwater over-pumping was the controlling factor of groundwater $\mathrm{Cl}^{-}$in coastal areas.

- Groundwater chemistry was predominantly controlled by the mechanism of geogenic rock dominance. The results of Pearson correlation and PCA collectively verified mineral dissolution or carbonate rock weathering as the major source of ions in groundwater, along with concurrence of evaporite dissolution.

- Expansion of monitoring stations to areas where the GQMN is not currently installed will provide a better evaluation of groundwater quality in the future.

Author Contributions: Conceptualization, methodology: C.-S.K., M.R., and J.-Y.L.; software: C.-S.K. and C.J.; validation: C.-S.K., J.-Y.L., and H.K.; investigation, resources: B.K., J.-W.K., and R.-H.K.; data curation, writing—original draft preparation, writing—review and editing: C.-S.K. and J.-Y.L.; visualization: C.-S.K. and C.J.; supervision: J.-Y.L. and H.K.; project administration: C.-S.K. and J.-Y.L.; funding acquisition, J.-Y.L. All authors have read and agreed to the published version of the manuscript.

Funding: This research was funded by Basic Science Research Program through the National Research Foundation of Korea (NRF) funded by the Ministry of Education (no. 2019R1A6A1A03033167). This work was also supported by Korea Environment Industry and Technology Institute (KEITI) through Measurement and Risk assessment Program for Management of Microplastics Program, funded by Korea Ministry of Environment (MOE) (2020003110010).

Acknowledgments: We would like to thank the anonymous reviewers for their suggestions and comments.

Conflicts of Interest: The authors declare that there is no conflict of interest.

\section{References}

1. Diamantini, E.; Lutz, S.R.; Mallucci, S.; Majone, B.; Merz, R.; Bellin, A. Driver detection of water quality trends in three large European river basins. Sci. Total Environ. 2018, 612, 49-62. [CrossRef]

2. $\mathrm{Xu}, \mathrm{B}$;; Wang, G. Surface water and groundwater contaminations and the resultant hydrochemical evolution in the Yongxiu area, west of Poyang Lake, China. Environ. Earth Sci. 2016, 75, 184. [CrossRef]

3. Li, P.; He, S.; Yang, N.; Xiang, G. Groundwater quality assessment for domestic and agricultural purposes in Yan'an City, northwest China: Implications to sustainable groundwater quality management on the Loess Plateau. Environ. Earth Sci. 2018, 77, 775. [CrossRef]

4. Lee, J.Y.; Raza, M.; Kwon, K.D. Land use and land cover changes in the Haean Basin of Korea: Impacts on soil erosion. Episodes 2019, 42, 17-32. [CrossRef]

5. Giri, S.; Qiu, Z. Understanding the relationship of land uses and water quality in Twenty First Century: A review. J. Environ. Manag. 2016, 173, 41-48. [CrossRef] [PubMed]

6. Jahnke, C.; Wannous, M.; Troeger, U.; Falk, M.; Struck, U. Impact of seawater intrusion and disposal of desalinization brines on groundwater quality in El Gouna, Egypt, Red Sea Area. Process analyses by means of chemical and isotopic signatures. Appl. Geochem. 2019, 100, 64-76. [CrossRef]

7. Yadav, S.; Babel, M.S.; Shrestha, S.; Deb, P. Land use impact on the water quality of large tropical river: Mun River Basin, Thailand. Environ. Monit. Assess. 2019, 191, 614. [CrossRef] [PubMed] 
8. Jiang, Y.; Wu, Y.; Groves, C.; Yuan, D.; Kambesis, P. Natural and anthropogenic factors affecting the groundwater quality in the Nandong karst underground river system in Yunan, China. J. Contam. Hydrol. 2009, 109, 49-61. [CrossRef]

9. Kim, S.G.; Kim, G.B. Are groundwater monitoring networks economical? Cost-benefit analysis on the long-term groundwater supply project of South Korea. Water 2019, 11, 753. [CrossRef]

10. Ministry of Environment and Korea Environment Institute. Management Method of Groundwater Monitoring System and Intensification with New Technology; Ministry of Environment: Sejong, Korea, 2018; pp. 31-48.

11. Duan, W.; He, B.; Nover, D.; Yang, G.; Chen, W.; Meng, H.; Zou, S.; Liu, C. Water quality assessment and pollution source identification of the eastern Poyang Lake Basin using multivariate statistical methods. Sustainability 2016, 8, 133. [CrossRef]

12. Raza, M.; Farooqi, A.; Niazi, N.K.; Ahmad, A. Geochemical control on spatial variability of fluoride concentrations in groundwater from rural areas of Gujrat in Punjab, Pakistan. Environ. Earth Sci. 2016, 75, 1364. [CrossRef]

13. Belkhiri, L.; Mouni, L.; Tiri, A. Water-rock interaction and geochemistry of groundwater from the Ain Azel aquifer, Algeria. Environ. Geochem. Health 2012, 34, 1-13. [CrossRef] [PubMed]

14. Stuart, M.; Chilton, P.; Kinniburgh, D.; Cooper, D. Screening for long-term trends in groundwater nitrate monitoring data. Q. J. Eng. Geol. Hydrogeol. 2007, 40, 361-376. [CrossRef]

15. Kim, J.; Ryoo, R.; Lee, J.; Song, D.; Lee, Y.J.; Jun, H.B. Study on major mineral distribution characteristics in groundwater in South Korea. J. Korean Soc. Environ. Eng. 2016, 38, 566-573. [CrossRef]

16. Lee, L.; Ahn, K.; Min, B.; Yang, M.; Choi, I.; Chung, H.; Park, J. The study on the ion water characteristics of raw water in the domestic natural mineral water. J. Korean Soc. Water Environ. 2016, 32, 442-449. [CrossRef]

17. Lee, J.Y.; Kwon, K.D.; Park, Y.C.; Jeon, W.H. Unexpected nationwide nitrate declines in groundwater of Korea. Hydrol. Process. 2017, 31, 4693-4704. [CrossRef]

18. Verma, S.; Mukherjee, A.; Mahanta, C.; Choudhury, R.; Mitra, K. Influence of geology on groundwatersediment interactions in arsenic enriched tectono-morphic aquifers of the Himalayan Brahmaputra river basin. J. Hydrol. 2016, 540, 176-195. [CrossRef]

19. Jeon, C.; Raza, M.; Lee, J.Y.; Kim, H.; Kim, C.S.; Kim, B.; Kim, J.W.; Kim, R.H.; Lee, S.W. Countrywide groundwater quality trend and suitability for use in key sectors of Korea. Water 2020, 12, 1193. [CrossRef]

20. Bacal, M.C.J.O.; Hwang, S.; Guevarra-Segura, I. Predictive lithologic mapping of South Korea from geochemical data using decision trees. J. Geochem. Explor. 2019, 205, 106326. [CrossRef]

21. Korea Environment Corporation. Investigation of Groundwater Quality by Groundwater Quality Monitoring Network; Korea Environment Corporation: Incheon, Korea, 2018; pp. 1-12.

22. Wetzel, H.A.; Mooi, E.; Sarstedt, M.; Mooi-Reci, I. Market Research: The Process, Data, and Methods Using Stata; Springer: Singapore, 2018; pp. 1-416.

23. A Correspondence Table for Non Parametric and Parametric Tests. Available online: https://blog.minitab.com/blog/applying-statistics-in-quality-projects/a-correspondence-table-for-nonparametric-and-parametric-tests (accessed on 27 August 2013).

24. Lee, S.Y.; Roh, Y.; Jeong, J.T. Changes of the oxidation/reduction potential of groundwater by the biogeochemical activity of indigenous bacteria. Econ. Environ. Geol. 2014, 47, 61-69. [CrossRef]

25. Oehler, T.; Eiche, E.; Putra, D.; Adyasari, D.; Hennig, H.; Mallast, U.; Moosdorf, N. Seasonal variability of land-ocean groundwater nutrient fluxes from a tropical karstic region (southern Java, Indonesia). J. Hydrol. 2018, 565, 662-671. [CrossRef]

26. Moujabber, M.E.; Samra, B.B.; Darwish, T.; Atallah, T. Comparison of different indicators for groundwater contamination by seawater intrusion on the Lebanese Coase. Water Resour. Manag. 2006, 20, 161-180. [CrossRef]

27. Lee, J.Y.; Hahn, J.S. Characterization of groundwater temperature obtained from the Korean national groundwater monitoring stations: Implications for heat pumps. J. Hydrol. 2006, 329, 514-526. [CrossRef]

28. Kaown, D.; Hyun, Y.; Bae, G.O.; Oh, C.W.; Lee, K.K. Evaluation of spatio-temporal trends of groundwater quality in different land uses using Kendall test. Geosci. J. 2012, 16, 65-75. [CrossRef]

29. Watari, T.; Kotcharoen, W.; Ormine, T.; Hatamoto, M.; Araki, N.; Oshiki, M.; Mimura, K.; Nagano, A.; Yamaguchi, T. Formation of denitrifying granules in an upflow sludge blanket reactor with municipal sewage and sodium nitrate feeding. Environ. Technol. Innov. 2020, 19, 100861. [CrossRef] 
30. Rajmohan, N.; Elango, L. Nutrient chemistry of groundwater in an intensively irrigated region of southern India. Environ. Geol. 2005, 47, 820-830. [CrossRef]

31. Hem, J.D. Study and Interpretation of the Chemical Characteristics of Natural Water, 3rd ed.; U.S. Government Printing Office: Washington, DC, USA, 1985; pp. 1-109.

32. Li, J.Y.; Li, T.Y. Seasonal and annual changes in soil/cave air $\mathrm{pCO}_{2}$ and the $\delta^{13} \mathrm{C}_{\mathrm{DIC}}$ of cave drip water in response to changes in temperature and rainfall. Appl. Geochem. 2018, 93, 94-101. [CrossRef]

33. Saha, S.; Reza, A.S.; Roy, M.K. Hydrochemical evaluation of groundwater quality of the Tista floodplain, Rangpur, Bangladesh. Appl. Water Sci. 2019, 9, 198. [CrossRef]

34. Woltersdorf, L.; Scheidegger, R.; Liehr, S.; Doll, P. Municipal water reuse for urban agriculture in Namibia: Modeling nutrient and salt flows as impacted by sanitation user behavior. J. Environ. Manag. 2016, 169, 272-284. [CrossRef]

35. Lee, C.S.; Gil, S.G.; Jeong, J.H.; Kim, J.H.; Choi, G.Y. Research for Effective Management and Reasonable Evaluation Standard of Eco-Friendly Fertilizer; Ministry for Food, Agriculture, Forestry and Fisheries: Sejong, Korea, 2012; pp. 1-149.

36. Park, S.C.; Yun, S.T.; Chae, G.T.; Yoo, I.S.; Shin, K.S.; Heo, C.H.; Lee, S.K. Regional hydrochemical study on salinization of coastal aquifers, western coastal aquifers, western coastal area of South Korea. J. Hydrol. 2005, 313, 182-194. [CrossRef]

37. Lee, H.; Koo, M.H.; Kim, K.; Kim, Y. Spatio-temporal variations in stream-aquifer interactions following construction of weirs in Korea. Groundwater 2015, 54, 448-458. [CrossRef] [PubMed]

38. Jeon, H.K.; Lee, Y.J.; Kang, S.S.; Yoon, H.B.; Hong, S.Y.; Kim, L.H.; Kim, Y.H.; Kim, M.S.; Seong, J.K.; Lee, J.Y.; et al. Manual of Fertilizer Recommendation Program of Heug-Toram; National Institute of Agricultural Sciences: Wanju, Korea, 2013; pp. 1-97.

39. Fertilizer Application. Available online: http://kosis.kr/statHtml/statHtml.do?orgId=101\&tblId=DT_ 2KAA415_OECD (accessed on 10 October 2019).

40. Kim, H.S.; Um, D.H.; Seo, I.G.; Kim, Y.I.; Kim, H.I.; Kim, H.J.; Kim, J.S.; Oh, K.Y.; Oh, S.Y. Environment Friendly Agricultural Infrastructures Scheme to Reduce Nutrients (N, P) Loading of Agricultural Drainage Water; Korea Rural Community Corporation: Naju, Korea, 2002; pp. 1-112.

41. Ministry of Environment. The Guidelines for Groundwater Quality Preservation; Ministry of Environment: Sejong, Korea, 2014; pp. 1-416.

42. Overbo, A.; Heger, S.; Kyser, S.; Asleson, B.; Gulliver, J. Chloride Contributions from Water Softeners and Other Domestic, Commercial, Industrial, and Agricultural Sources to Minnesota Waters; University of Minnesota: Minneapolis, MN, USA, 2019; pp. 1-34.

43. Eo, H.J.; Kim, J.S. Analysis of correlations between mineral contents in waters and sensory characteristics of coffee. Culi. Sci. Hos. Res. 2017, 23, 105-115.

44. Statistics of Sewer Pipe in 2018. Available online: http://me.go.kr/home/web/policy_data/read.do? pagerOffset=0\&maxPageItems=10\&maxIndexPages $=10 \&$ searchKey $=\&$ searchValue $=\&$ menuId $=10264 \&$ $\operatorname{org} C d=\&$ condition. $\operatorname{code}=A 5 \&$ condition.deleteYn=N\&seq=7440 (accessed on 31 December 2019).

45. Zhang, B.; Zhao, D.; Zhou, P.; Qu, S.; Liao, F.; Wang, G. Hydrochemical characteristics of groundwater and dominant water-rock interactions in the Delingha Area, Qaidam Basin, Northwest China. Water 2020, $12,836$. [CrossRef]

46. Marandi, A.; Shand, P. Groundwater chemistry and the Gibbs diagram. Appl. Geochem. 2018, 97, $209-212$. [CrossRef]

47. Sarwade, D.V.; Nandakumar, M.V.; Kesari, M.P.; Mondal, N.C.; Singh, V.S.; Singh, B. Evaluation of seawater ingress into an Indian atoll. Environ. Geol. 2007, 52, 1475-1483. [CrossRef]

48. Sidhu, N.; Rishi, M.S.; Herojeet, R.K. Groundwater quality variation with respect to aquifer dispositioning in urbanized watershed of Chandigarh, India. Int. J. Environ. Ecol. Fam. Urban Stud. 2013, 3, 87-98.

49. Pant, R.R.; Zhang, F.; Rehman, F.U.; Wang, G.; Ye, M.; Zeng, C.; Tang, H. Spatiotemporal variations of hydrogeochemistry and its controlling factors in the Gandaki River Basin, Central Himalaya Nepal. Sci. Total Environ. 2018, 622, 770-782. [CrossRef]

50. Li, C.; Gao, X.; Wang, Y. Hydrogeochemistry of high-fluoride groundwater at Yuncheng Basin, northern China. Sci. Total Environ. 2015, 508, 155-165. [CrossRef] 
51. Kaown, D.; Koh, D.C.; Yu, H.E.; Kim, H.; Yoon, Y.Y.; Yum, B.W.; Lee, K.K. Combined effects of recharge and hydrogeochemical conditions on nitrate in groundwater of a highland agricultural basin based on multiple environmental tracers. Agric. Water Manag. 2020, 240, 106327. [CrossRef]

Publisher's Note: MDPI stays neutral with regard to jurisdictional claims in published maps and institutional affiliations.

(C) 2020 by the authors. Licensee MDPI, Basel, Switzerland. This article is an open access article distributed under the terms and conditions of the Creative Commons Attribution (CC BY) license (http://creativecommons.org/licenses/by/4.0/). 